\title{
Evropa med mitom in stvarnostjo
}

Lani se je uredništvo revije Ars et humanitas odločilo, da letošnjo številko posveti Evropi. Veseli nas, da so se vabilu k sodelovanju odzvali skoraj vsi povabljeni tuji in domači raziskovalci.

Yves Chevrel v svoji razpravi, ki jo je predstavil tudi februarja letos na Festivalu zgodb Fabula v Cankarjevem domu, razmišlja o Evropi z gledišča prevajanja: Evropa je celina prevajanja, prevod pa nas povezuje, četudi Francozi s sintagmo »invazije barbarov« označujejo pojav, ki ga slovensko in nemško zgodovinopisje imenujeta "preseljevanje narodov«. Miloš Zelenka v svojem prispevku osvetljuje minimalistični in maksimalistični koncept pojma Srednja Evropa v literarnem diskurzu 20. stoletja. Razprava Anne Zelenkove se osredinja na skoraj pozabljeno delo Das Slawenthum und die Welt der Zukunft (Slovanstvo in svet bodočnosti) L'udovíta Štúra, v katerem se pojavlja zelo zanimiva delitev na evropski materialistični Zahod (Nemci, Čehi) in evropski duhovno-zgodovinski Vzhod (Slovaki, Rusi).

V nadaljevanju pa se razpravljavci dotikajo evropske problematike še na drugih področjih. Gregor Pompe se v svojem članku sprašuje, ali obstaja evropska glasba, in odgovarja pritrdilno. Martina Ožbot in Oliver Currie pa orisujeta nekaj potez današnje Evrope s stališča njenih jezikov. V zadnjem tematskem prispevku pa Jernej Zupančič ugotavlja, da bodo meje obstajale tudi v prihodnje. Mit Evrope in stvarnost Evrope pač nista vedno identična, kar najbrž dokazuje tudi naše štiriletno bivanje pod evropskimi zvezdami.

Urednik tematskega bloka: Tone Smolej 